\title{
Distribution patterns of planktivorous reef fish along the coast of northeastern New Zealand
}

\author{
Michael J. Kingsford* \\ University of Auckland, Zoology Department, Marine Laboratory, R. D. Leigh, New Zealand
}

\begin{abstract}
Broad-scale distribution patterns of planktivorous reef fish were described using visual counts along $100 \mathrm{~km}$ of the coast of Northland, New Zealand; including sampling at islands across the continental shelf. Temporal variation in abundance was examined also. Comparisons between strip transects and rapid visual counts (RVC's) indicated that RVC's were most appropriate for a broad-scale survey. Different abundance patterns were found for 13 species of planktivorous fish. Some species exhibited significant differences across the shelf (e.g. Chromis dispilus and Scorpis aequipinnis). No cross-shelf differences were detected for others (e.g. Casioperca lepidoptera and Pseudocaranx dentex). Abundance of 2 species differed along a north-south axis. The proportional representation of species varied within the study area. C. dispilus dominated over a large part of the study area. The southwestern region had a high proportion of $S$. aequipinnis and/or Trachurus novaezelandiae. Over $5 \mathrm{yr}$ the composition of fish at an outer-shelf and inner-shelf location remained similar Two groups of planktivorous fish were identified, those with a close association (e.g. C. dispilus) and those which a temporary association with reefs (e.g. Trachurus novaezealandiae). The first group showed little variation in abundance at 2 sites over $15 \mathrm{mo}$, while the other exhibited considerable temporal variation. Regular variation in abundance at different times of the day was not found for either group. It is suggested that hydrology may influence the composition and abundance of zooplankton which may influence survivorship of presettlement reef fish and the feeding of fish on reefs. Investigation of proximate factors which may determine the distribution patterns of planktivorous fish is required
\end{abstract}

\section{INTRODUCTION}

Planktivorous reef fish are abundant on coral and temperate rocky reefs. Studies have indicated these fish are potentially important in that they may: (1) cause localised reductions in the abundance of zooplankton, (2) consume larval forms leaving a reef or approaching a reef io settle, and (3) be responsible for enhanced nutrient input into reef systems (Hobson \& Chess 1976, Bray 1981, Bray et al. 1981, 1986, Robertson 1982, Gaines \& Roughgarden 1987, Kingsford \& MacDiarmid 1988).

Whether the imprortance of planktivorous fish alters according to the abundance and species composition of fish is unknown. There is limited information on the distribution patterns of fish within reef systems, and over broad geographic areas (e.g. over tens of $\mathrm{km}$ ). Broad-scale patterns have been identified in tropical waters (Williams Hatcher 1983), but in temperate

\footnotetext{
- Present address: School of Biological Sciences A08, University of Sydney, N.S.IV. 2006, Australia
}

environments, distributions of planktivorous fish have been examined only at a small number of locations along the coast of California (USA) and New Zealand. These studies have been primarily concerned with relationships between, fish and plankton (Bray 1981, Kingsford \& MacDiarmid 1988), fish and kelp (Ebeling et al. 1980, Larson \& DeMartini 1984) and day versus night activity of fish (Ebeling \& Bray 1976), or one-off surveys of a location (Russell 1977). Broad-scale abundance patterns are undescribed.

The aim of this study was to describe the broad-scale distribution patterns of planktivorous reef fish along a stretch of the coast of Northland, New Zealand. An important part of the sampling was to estimate abundance at locations on the mainland and islands across the continental shelf.

Consideration of 3 aspects of procedure and design is required before a broad-scale survey of planktivorous fish. (1) Choice of a method (e.g. transects or rapid visual counts - RVC's; Bortone et al. 1986); (2) distributions of fish are adequately described on a small scale $(<2 \mathrm{~km})$ within a reef system before comparisons are 
made between them (Russ 1984); (3) abundance of fish may fluctuate within and between years (Ebeling et al. 1980, Jones 1984, Choat \& Ayling 1987, Choat et al. 1988). Interpretation of the consistency of broad-scale patterns, therefore, required information on temporal changes in abundance. These aspects were addressed in this study, so that it would allow more detailed investigations concerning the dynamics of reef environments and the population dynamics of fish.

\section{MATERIALS AND METHODS}

Strip transect versus RVC. Counting fish that feed in large aggregations in the water column, move around the reef and include species that are highly mobile (e.g. carangids) constitutes a sampling problem (Larson \& DeMartini 1984, Thresher \& Gunn 1986). Many of these fish frequent areas with rapid currents and complex bathymetry (Hobson \& Chess 1978). The literature on methodology for assessing the abundance of reef fish is broad (e.g. Bortone et al. 1986). Two methods that have been commonly used to describe distribution patterns of planktivorous reef fish are strip transects (Bray 1981, Kingsford \& MacDiarmid 1988) and time counts (rapid visual techniques - RVC's; e.g. Williams 1982). I wanted to determine if transects or RVC's gave a more accurate picture of the distribution patterns of planktivorous reef fish over a broad area.

My assessment of these techniques involved a comparison of abundance patterns of planktivorous fish along the coast of Northland, New Zealand. Counts were made at 4 locations (the Poor Knights Islands, Chickens group, Hen Island, Goat Island) and at 5 sites within each location (Fig. 1). Fish abundance was estimated in 5 transects and 5 RVC's at each site, on the same day. Transects were $25 \times 10 \mathrm{~m}$ and were measured by sampling an estimated $5 \mathrm{~m}$ on each side of a $25 \mathrm{~m}$ tape. The number of replicate transects was determined by the maximum safe time a diver could spend at $20 \mathrm{~m}$. The data were recorded as number per $250 \mathrm{~m}^{2}$. Transects were compared with 3-min RVC's. Replicate RVC's were used instead of a single count (e.g. Williams 1982) to gain some estimate of variation in abundance within a sampling site. To estimate the distance travelled in 3 min, 3 replicate RVC's were carried out while swimming over a tape at sites 1,2 and 3 in the Goat Island Marine Reserve; distances ranged from 36 to $44 \mathrm{~m}$ (Mean $40 \mathrm{~m}$ ). The greatest variability was found at sites with strong currents (ca $25 \mathrm{~cm} \mathrm{~s}^{-1}$ ), whereas counts at sites with no current covered areas of a similar size. Fish were only counted within a $10 \mathrm{~m}$ lane. Hence, RVC's covered ca $400 \mathrm{~m}^{2}$. The data were recorded as $\log _{3}$ categories according to Russ (1984; $1=1, \quad 2=2-3, \quad 3=4-9, \quad 4=10-27, \quad 5=28-81, \quad 6=$

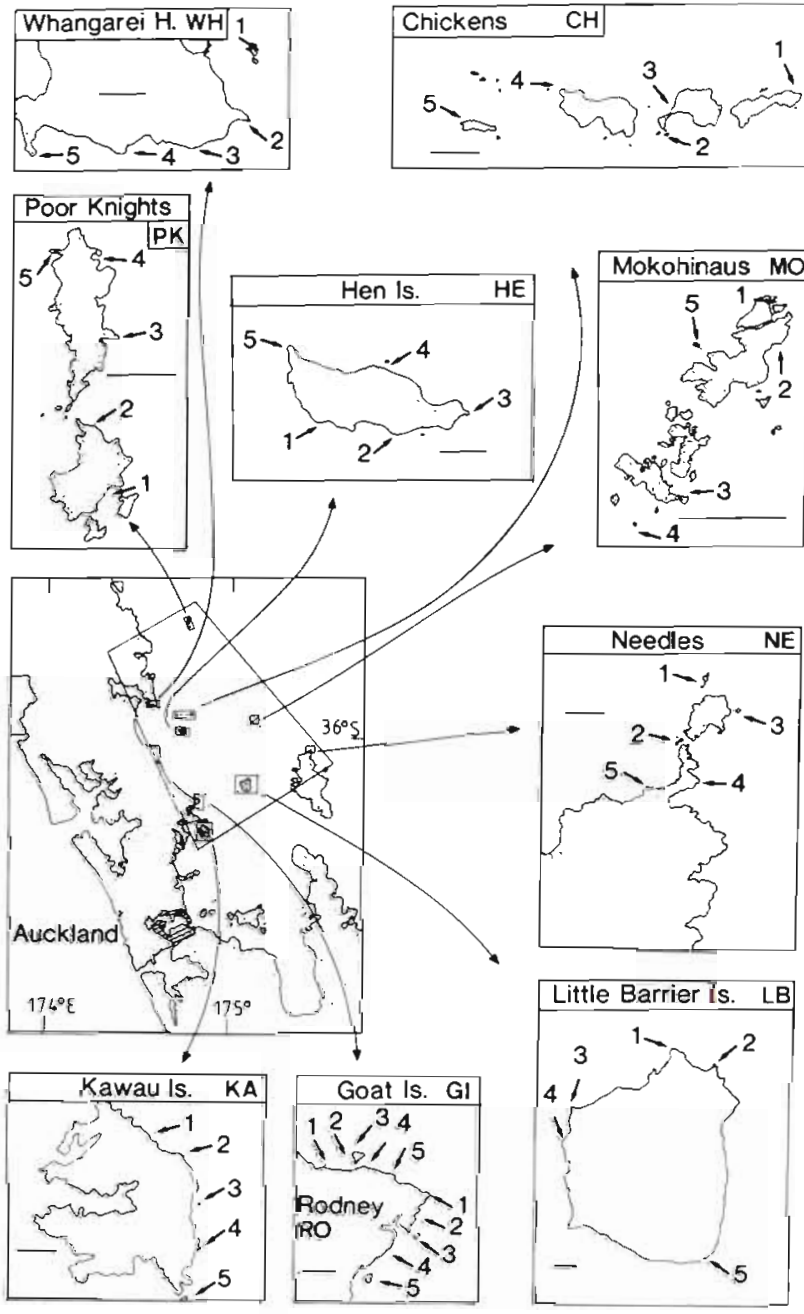

Fig. 1. Northeastern New Zealand showing study area. Planktivorous fish were sampled at the 10 locations indicated. These are discussed according to distance from the mainland; outer shelf ( $\mathrm{PK}, \mathrm{MO}, \mathrm{NE})$; mid shelf $(\mathrm{CH}, \mathrm{HE}, \mathrm{LB})$ and inner shelf (WH, GI, RO, KA). Numbers 1 to 5 indicate sites within each location. Scale bars $=1 \mathrm{~km}$. The watermass to the south of Kawau Island is the Hauraki Gulf

$82-243,7=244-729,8=730-2187$ fish). Analyses were carried out using the median value of a $\log$ category. Comparisons between strip transects and RVC's indicated that RVC's were most appropriate for the survey (see 'Results'). Fish were counted in 5 replicate RVC's at each site.

Survey of planktivorous reef fish. The study was carried out on rocky reefs along a $100 \mathrm{~km}$ stretch of the northeastern coast of Northland (Fig. 1) from mid-September 1986 to early February 1987. Planktivorous fish were counted at 3 locations near the outer edge of the shelf (Poor Knights, Mokohinaus, Needles), 3 mid shelf (Chickens, Hen Island, Little Barrier Island), and 3 near the mainland (Whangarei Heads, Rodney, and Kawau Island). Data from the Goat Island Marine Reserve, 
where strip transects were compared with RVC's are also presented. Mainland locations were separated from those on the outer shelf edge by at least $55 \mathrm{~km}$. Fish were counted at 5 sites at each location (Fig. 1). All sites were exposed to the open sea. I attempted to sample on all sides of islands because wind or current direction often influence the abundance patterns of fish (Williams 1982, Kingsford \& MacDiarmid 1988).

Fish were counted throughout the entire water column at many sites characterised by steep drop offs. Gradually sloping reefs were encountered also, especially at sites around the mainland. In this situation counts were made while swimming a zig-zag path over the reef; this minimized the possibility of missing fish restricted to deep or shallow water (Kingsford 1980, MacDiarmid 1981). The depths to which counts were made at each site was recorded using an oil-filled depth gauge. Information on subtidal habitats was reported for the Poor Knights Islands, Little Barrier, and Goat Island by Choat \& Schiel (1982). Most study sites conformed to their general description of habitats: fucoid algae dominated the shallow subtidal; laminarian (Ecklonia radiata) stands and echinoids dominated areas midway down the reef and; algal stands

Table 1. Total planktivores observed in the survey. Some species feed facultatively on the plankton (pers. obs.); the feeding guild to which they normally belong is given (according to Doak 1972, Ayling \& Cox 1982, Russell 1983, Choat \& Ayling 1987). Feeding guilds: B, benthic predator; F, piscivore; $\mathrm{H}$, herbivore; P, planktivore. Fish are named according to Paulin \& Stewart (1985)

\begin{tabular}{|c|c|c|}
\hline Species & Common name & Feeding guild \\
\hline \multicolumn{3}{|l|}{$\begin{array}{l}\text { Fish counted in survey } \\
\text { SERRANIDAE }\end{array}$} \\
\hline Caesioperca lepidoptera (Bloch \& Schneider) & Butterfly perch & $P$ \\
\hline Callanthias allporti (Gunther) & Splendid perch & $\mathrm{P}$ \\
\hline Caprodon longimanus (Gunther) & Pink mao mao & $\mathrm{P}$ \\
\hline $\begin{array}{l}\text { LABRACOGLOSSIDAE } \\
\text { Bathystethus cultratus (Bloch \& Schneider) } \\
\text { Labracoglossus nitida (McCulloch \& Waite) }\end{array}$ & $\begin{array}{l}\text { Grey knifefish } \\
\text { Blue knifefish }\end{array}$ & $\begin{array}{l}\mathrm{P} \\
\mathrm{P}\end{array}$ \\
\hline $\begin{array}{l}\text { CARANGIDAE } \\
\text { Decapterus koheru (Hector) } \\
\text { Pseudocaranx dentex (Bloch \& Schneider) } \\
\text { Trachurus novaezelandiae (Richardson) }\end{array}$ & $\begin{array}{l}\text { Koheru } \\
\text { Trevally } \\
\text { Horse mackerel }\end{array}$ & $\begin{array}{l}P \\
P \\
P\end{array}$ \\
\hline $\begin{array}{l}\text { ARRIPIDAE } \\
\text { Arripis trutta (Bloch \& Schneider) }\end{array}$ & Kahawai & $\mathrm{PF}$ \\
\hline $\begin{array}{l}\text { KYPHOSIDAE } \\
\text { Scorpis aequipinnis (Richardson) } \\
\text { Scorpis violaceus (Hutton) }\end{array}$ & $\begin{array}{l}\text { Sweep } \\
\text { Blue mao mao }\end{array}$ & $\begin{array}{l}\mathrm{P} \\
\mathrm{P}\end{array}$ \\
\hline $\begin{array}{l}\text { POMACENTRIDAE } \\
\text { Chromis dispilus (Griffin) } \\
\text { Chromis hypsilepis (Gunther) }\end{array}$ & $\begin{array}{l}\text { Two-spot demoiselle } \\
\text { One-spot demoiselle }\end{array}$ & $\begin{array}{l}\mathrm{P} \\
\mathrm{P}\end{array}$ \\
\hline $\begin{array}{l}\text { Casual observations } \\
\text { ENGRAULIDAE } \\
\text { Engraulis australis (White) }\end{array}$ & Anchovy & $\mathrm{P}$ \\
\hline $\begin{array}{l}\text { HEMIRHAMPHIDAE } \\
\text { Hyporhamphus ihi (Phillips) }\end{array}$ & Piper & $\mathrm{P}$ \\
\hline $\begin{array}{l}\text { CARANGIDAE } \\
\text { Seriola lalandi (Cuvier \& Valenciennes) } \\
\text { Trachurus declivis (Jenyns) }\end{array}$ & $\begin{array}{l}\text { Kingfish } \\
\text { Jack mackerel }\end{array}$ & $\begin{array}{l}F \\
P\end{array}$ \\
\hline $\begin{array}{l}\text { KYPHOSIDAE } \\
\text { Girella tricuspidata (Quoy \& Gaimard) }\end{array}$ & Parore & $\mathrm{H}$ \\
\hline $\begin{array}{l}\text { LABRIDAE } \\
\text { Pseudolabrus celidotus (Bloch \& Schneider) }\end{array}$ & Spotty & $\mathrm{B}$ \\
\hline $\begin{array}{l}\text { TRIPTERYGIIDAE } \\
\text { Obliquichthys maryannae (Hardy) }\end{array}$ & Oblique swimming blenny & $\mathrm{P}$ \\
\hline $\begin{array}{l}\text { SCOMBRIDAE } \\
\text { Scomber australasicus (Cuvier \& Valenciennes) }\end{array}$ & Blue mackerel & $\mathrm{P}$ \\
\hline $\begin{array}{l}\text { MONACANTHIDAE } \\
\text { Parika scaber (Bloch \& Schneider) }\end{array}$ & Leather jacket & $\mathrm{B}$ \\
\hline
\end{tabular}


and sometimes sponge dominated areas in deep water. Accordingly, counts over gradually sloping reef traversed a number of habitats. Encrusting organisms such as sponges and ascidians were abundant on vertical faces at offshore islands (Battershill \& Stocker pers. comm.).

A total of 13 species of planktivorous fish were counted and incidental observations of another 9 species were made during the survey (Table 1). A small planktivorous tripterygiid, the oblique swimming blenny Obliquichthys maryannae, was observed in aggregations near the substratum, especially at offshore islands. It was not counted in RVC's during the survey. Some species of fish were observed feeding on plankton that are generally associated with another feeding guild (Table 1).

Temporal variation in abundance. Planktivorous reef fish were sampled at Sites 3 and 4 within the Goat Island Marine Reserve over 15 mo in 1981 and 1982. At each sampling time fish were counted in 5 replicate $50 \times 10 \mathrm{~m}$ transects. Abundances are expressed as number per $400 \mathrm{~m}^{2}$ for comparisons with the 1986 broad-scale survey. For an assessment of variation in abundance at different times of the day counts were made early $(07: 30$ to $09: 00 \mathrm{~h})$, mid $(12: 30$ to $14: 00 \mathrm{~h}$ ) and late (16:30 to $17: 39 \mathrm{~h}$ ) during September 1981 over a period of $17 \mathrm{~d}$.

Data analysis. Where appropriate the abundance patterns of individual species were analysed using 3factor partially hierarchical analyses of variance, following the conventions of Underwood (1981). The fixed factor distance (D) had 3 levels: inner, mid, outer. Position (P) was treated as a fixed factor and orthogonal with distance. Positions ranked from North to South, Positions 1 to 3 . Nine locations were analysed within the array of distance and position. Sites at each location were nested within the interaction $(D \times P)$. Site was treated as a random factor. A total of 7 tests were carried out on separate groups of fish. For this reason factors were only considered significant at 0.005 according to Bonferroni $(0.05 / 7$; taken to 0.005$)$. Cochran's test was used to test for homogeneity of variance (variances $=45, \mathrm{df}=4$ ). If this analysis was significant, the data were transformed and tested again. Ryan's tests were used for a posteriori comparisons among means at the 0.05 level (Begun \& Gabriel 1981, R. Day \& J. Quinn pers. comm.)

Analyses of differences in species composition were carried out using data for all species $(n=13)$ and locations $(n=10)$. These were transformed into a proportional similarity matrix, using the recommendations of Kohn \& Riggs (1982). Similarity coefficients were calculated using the cluster analysis of GENSTAT (CSIRO network Australia) with the average linkage procedure.

\section{RESULTS}

\section{Strip transect versus RVC}

Significant differences in the abundance of planktivorous fish were detected among locations using strip transets and RVC's (Fig. 2, Table 2). Both techniques
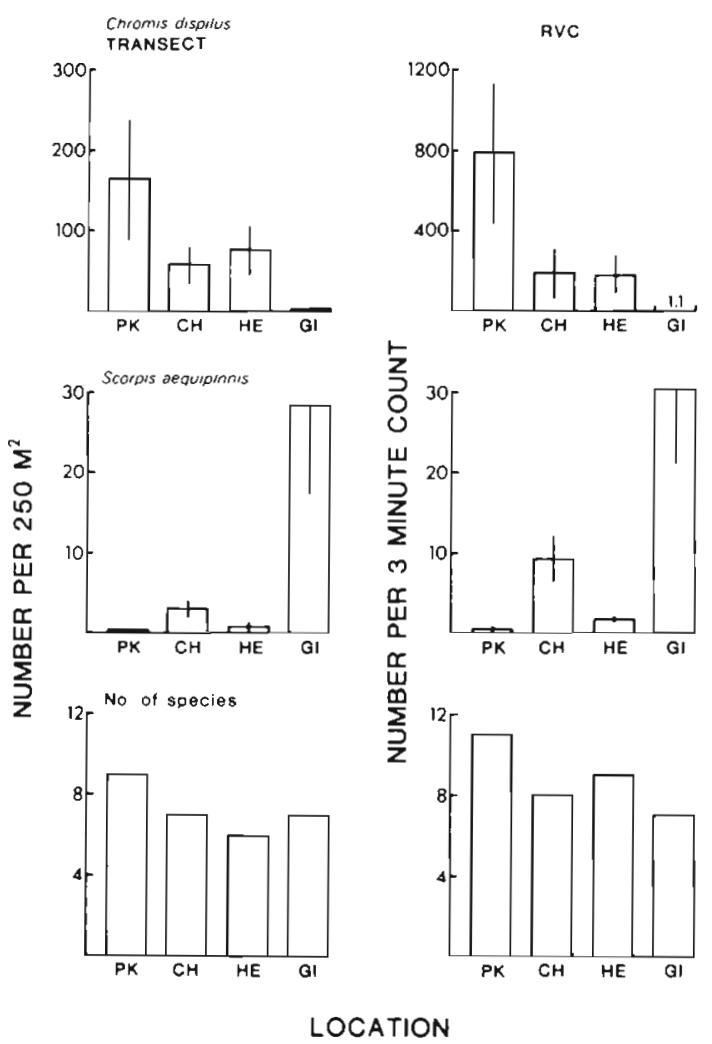

Fig. 2. Comparison of strip transects and rapid visual counts (RVC's) at 4 locations. Comparisons are made for 2 of the most abundant species of planktivorous fish and the total number of species found at each location. Values equal the mean of 5 sites ( $\pm \mathrm{SE}$; only 0.5 of this bar is given on some columns), $n=5$ replicates at each site. Locations shown in Fig. 1

showed similar patterns of abundance. Chromis dispilus was found in highest densities at the Poor Knights Islands and lowest densities at Goat Island. In contrast, very low densities of Scorpis aequipinnis were found at the Poor Knights and high number at Goat Island. Direct comparisons were made between transects and RVC's using Spearman's rank correlation coefficient $(r$; Siegel 1956). Significant correlations of rank abundance were obtained for fish at 20 sites, total fish $(r=0.72, p<0.01), C$. dispilus $(r=0.976, p<0.01)$, and $S$. aequipinnis $(r=0.736, p<0.01)$.

More species were detected using RVC's (Fig. 2). It took ca $45 \mathrm{~min}$ to complete 5 transects and these were often difficult to deploy, especially on vertical drop offs. In contrast it took ca 20 min to complete 5 replicate 
Table 2. Results of 2-factor analyses of variance for densities of fish estimated at 4 locations using strip transects and RVC's. See 'Materials and methods' for details of analyses. All Cochran's tests for homogeneity of the data were not significant at 0.05 for the raw data only. Data transformation for all tests $\log _{e}(x+1)$. df: degrees of freedom for $F$-test, probability levels $\cdot 0.005, \cdots 0.001$

\begin{tabular}{|c|c|c|c|c|c|c|c|}
\hline \multirow{2}{*}{$\begin{array}{l}\text { Source of } \\
\text { variation }\end{array}$} & \multirow[t]{2}{*}{$\mathrm{df}$} & \multicolumn{3}{|c|}{ Chromis dispilus } & \multicolumn{3}{|c|}{ Scorpis aequipinnis } \\
\hline & & MS & $F$ & $p$ & MS & $F$ & $p$ \\
\hline \multicolumn{8}{|c|}{ Strip transects } \\
\hline Location & 3,16 & 71.21 & 14.5 & $\cdots$ & 20.66 & 6.1 & • \\
\hline Site (L) & 16,80 & 4.89 & 4.2 & $\cdots$ & 3.39 & 4.3 & $\cdots$ \\
\hline Residual & 80 & 1.15 & & & 80 & & \\
\hline \multicolumn{8}{|l|}{ RVC's } \\
\hline Location & 3,16 & 137.04 & 21.1 & $\cdots$ & 17.13 & 9.2 & $\cdot$ \\
\hline Site (L) & 16,80 & 6.27 & 6.2 & $\because$ & 1.86 & 1.2 & NS \\
\hline Residual & 80 & 1.01 & & & 1.63 & & \\
\hline
\end{tabular}

RVC's. Similar patterns of abundance were found for common species of fish with both techniques. RVC's, however, were quicker and covered a wider area which allowed rare species and widely spaced aggregations of fish to be detected. Fish were enumerated on 1 st encounter with RVC's reducing the chance of scaring fish away from the area of counts. My conclusion from this comparison was that RVC's were most appropriate for a broad-scale survey.

\section{Abundances of planktivorous reef fish}

Contrasting patterns of abundance were found for the 9 most abundant species of fish (Figs. 3 to 5). Chromis dispilus was most abundant on reefs at mid and outer areas of the shelf (Fig. 3). Lowest abundances were found at inner locations (Ryan's test: $\mathrm{df}=36$, $\mathrm{O}=\mathrm{M}>\mathrm{I}$ ). Although highest average abundances were found at 2 outer locations ( $\mathrm{PK}$ and $\mathrm{MO}$ ), abundance at the southernmost, outer, location (NE) was similar to that at mid shelf locations. Average abundance decreased in north-south direction at all 3 levels of distance across the shelf (Factor position, Table 3 ). Similar densities were found at the Chickens and Hen (mid) reflecting their close proximity to each other. Significant differences were found among sites at any one location (Table 3). For example, no C. dispilus were found at Sites 4 and 5 at Rodney (Inner) while 27 ( \pm 12 , SE) were found at Site 1 (Fig. 1). Where fish were abundant they were found in large aggregations. This resulted in large standard errors within sites.

Scorpis aequipinnis showed the opposite pattern to Chromis dispilus (Fig. 3). Highest densities were observed at inner locations and very few fish were found near the outer edge of the shelf (Factor distance; Table 3). Highest densities were observed at inner locations and very few fish were found near the outer edge of the shelf (Factor distance; Table 3). Although

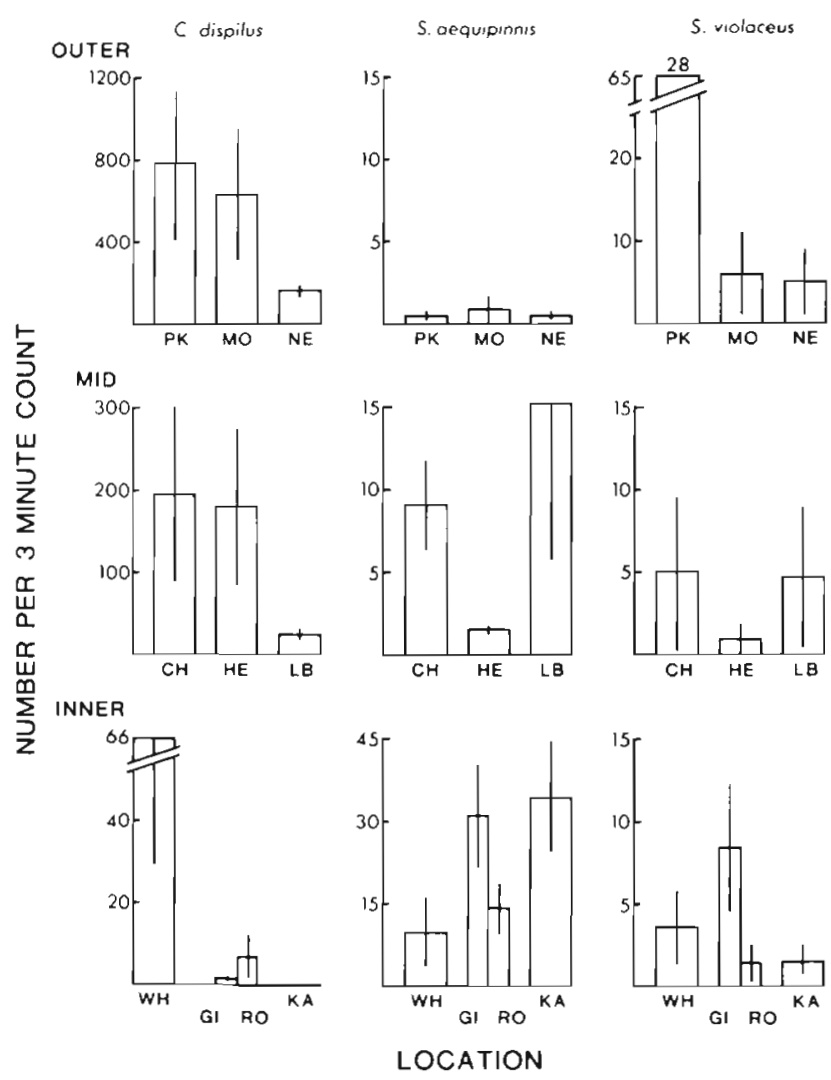

Fig. 3. Chromis dispilus, Scorpis aequipinnis, Scorpis violaceus. Abundance patterns of planktivorous reef fish at inner shelf, mid shelf, and outer shelf locations. Results of analyses on these data are given in Table 3 . Values equal the mean of 5 sites ( $\pm \mathrm{SE}$, the value given at the top of 1 bar indicates $S E$ ),

$n=5$ replicates at each site. Locations shown in Fig. 1

there was a trend for highest abundance at the southern end of the study area, latitudinal position was not significant. Values of zero were recorded at some sites. Large differences among replicates, due to aggregation behaviour, obscured differences among sites; note the high residual mean square (Table 3 ). 
Table 3. Results of 3-factor partially hierarchical analyses of variance for 6 fish species. See 'Materials and methods' for details of analyses. Data transformation for all tests $\log _{e}(x+1)$. All Cochran's tests for homogeneity of data were not significant at 0.05 for raw data only. df for F-test, probability levels $\cdot 0.005, \cdots 0.001$

\begin{tabular}{|c|c|c|c|c|c|c|c|c|c|c|}
\hline $\begin{array}{l}\text { Source of } \\
\text { variation }\end{array}$ & df & MS & F & $p$ & MS & $F$ & $p$ & MS & $F$ & $p$ \\
\hline & & \multicolumn{3}{|c|}{ C. dispilus } & \multicolumn{3}{|c|}{ S. aequipinnis } & \multicolumn{3}{|c|}{ S. violaceus } \\
\hline Distance & 2,36 & 301 & 49.5 & $\cdots$ & 19.4 & 7.4 & - & 11.8 & 3.5 & \\
\hline Position & 2,36 & 64 & 10.5 & $\cdots$ & 8.3 & 3.2 & & 9.3 & 2.8 & \\
\hline Site (DP) & 36,180 & 6.1 & 5.5 & $\cdots$ & 2.6 & 1.5 & & 3.4 & 3.1 & $\cdots$ \\
\hline $\mathrm{D} \times \mathrm{P}$ & 4,36 & 14 & 2.3 & & 2.1 & 0.8 & & 7.2 & 2.1 & \\
\hline \multirow[t]{2}{*}{ Residual } & 180 & 1.1 & & & 1.7 & & & 1.1 & & \\
\hline & & \multicolumn{3}{|c|}{ C. lepidoptera } & \multicolumn{3}{|c|}{ D. koheru } & \multicolumn{3}{|c|}{ T. novaezelandiae } \\
\hline Distance & 2,36 & 1 & 0.5 & & 2.0 & 1 & & 11.9 & 2.9 & \\
\hline Position & 2,36 & 5.9 & 1.5 & & 8.3 & 3.9 & & 5.8 & 1.4 & \\
\hline Site (DP) & 36,180 & 2.0 & 3.6 & $\cdots$ & 2.1 & 3.0 & $\cdots$ & 4.1 & 6.8 & $\cdots$ \\
\hline$D \times P$ & 4,36 & 2.0 & 1.0 & & 3.1 & 1.5 & & 9.7 & 2.4 & \\
\hline Residual & 180 & 0.6 & & & 0.7 & & & 0.6 & & \\
\hline
\end{tabular}

Scorpis violaceus was found across the shelf and no north-south trend was observed. Highest average densities were found at the Poor Knights Islands (Outer) where aggregations of 100 to 500 individuals occurred. Here and elsewhere, $S$. violaceus was characterized by large differences among sites (Table 3 ).

Low average densities of Caesioperca lepidoptera were found at all locations, regardless of distance across the shelf or latitudinal position (Fig. 4). Significant differences were found among sites (Table 3). This was particularly conspicuous at Rodney (inner) where mean densities at each site were 1.2 (Site 1), o(Site 2), 26 (Site 3), 3.8 (Site 4), 0 (Site 5).

Caprodon longimanus was only found on the outer edge of the shelf (Fig. 4). Highest average abundances were found at the northern position of the study area (PK). One individual only was observed at the Needles. At the Poor Knights $C$. longimanus was observed in aggregations of over 200 at Sites 3 and 5 (Fig. 1) while low numbers were observed at other sites.

Arripis trutta were observed at all distances (Fig. 4). Although these fish were not recorded in counts at the Poor Knights (outer), Kawau and Rodney (inner) casual observations were made of fish at all but the Poor Knights. The data were not analysed using analysis of variance as only 12 of a total 225 replicate counts included this species.

Abundances of 3 species of carangids are presented in Fig. 5. With the exception of Kawau (inner) Decapterus koheru were found at all locations. Highest mean densities, due to large schools, were found at the Poor Knights Islands on the outer edge of the shelf. Significant differences were found among sites (Table 3).

Trachurus novaezelandiae were only observed on the inner and mid shelf (Fig. 5). Further, almost all of the $T$. novaezelandiae were observed in the southwestern

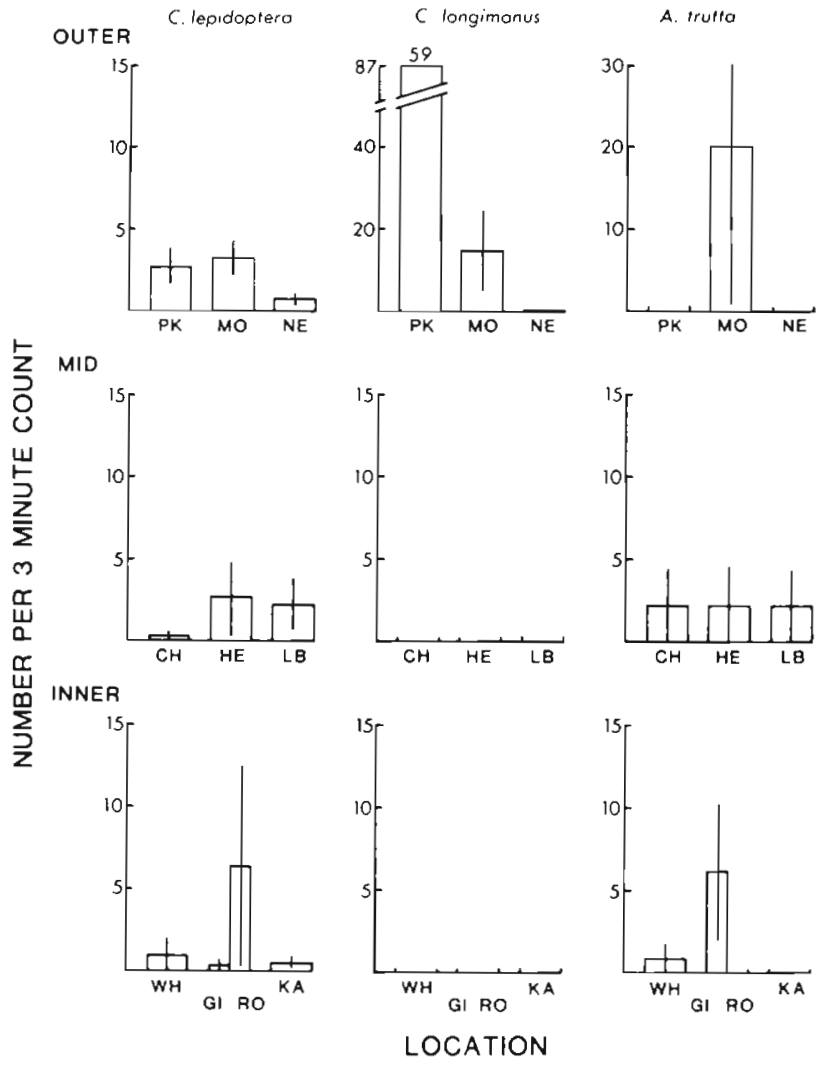

Fig. 4. Caesioperca lepidoptera, Caprodon longimanus, Arripis trutta. Abundance of 3 species of planktivorous reef fish at inner, mid, and outer shelf locations; values: see Fig. 3

corner of the study area (LB, GI, RO, KA). Large differences were found among sites (Table 3 ) and where fish were abundant they were found in large schools.

With the exception of Kawau Is., abundances of Pseudocaranx dentex were low at all locations (Fig. 5). Some species of planktivorous fish were rare. A few 


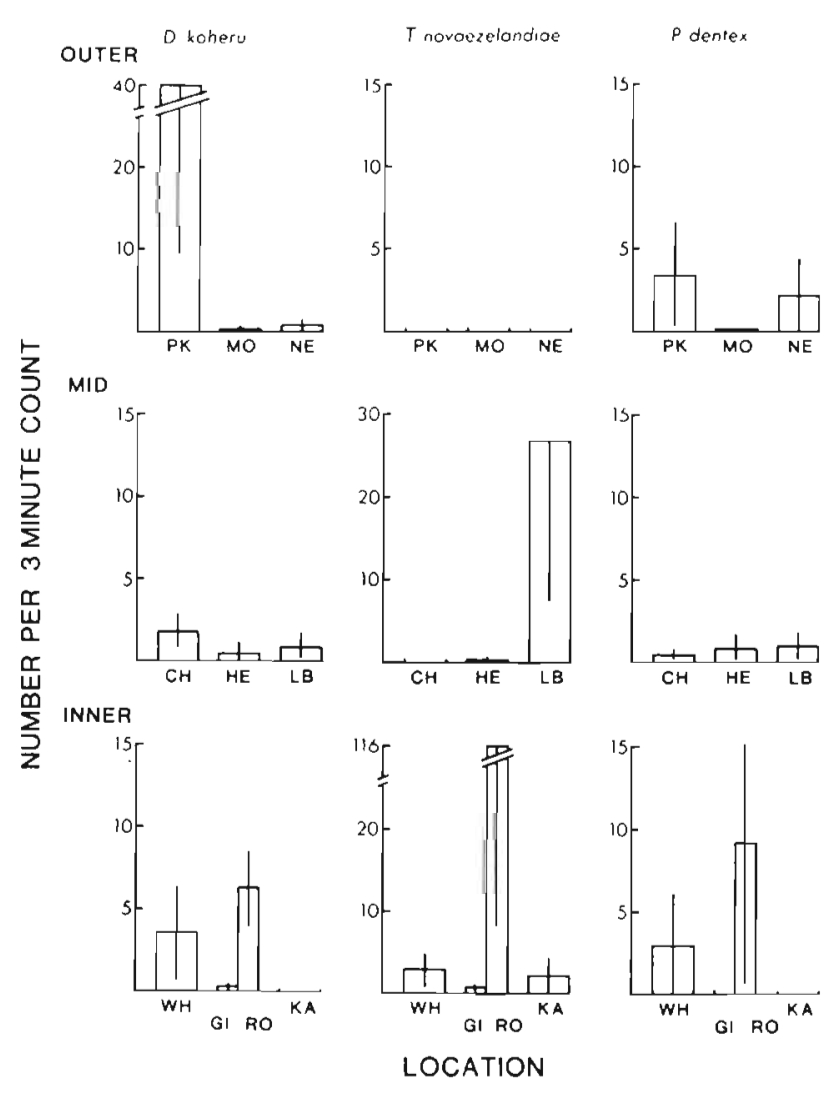

Fig. 5. Decapterus koheru, Trachurus novaezelandiae, Pseudocaranx dentex. Abundance of 3 species of planktivorous carangids at inner shelf, mid shelf, and outer shelf locations; values: see Fig. 3

individuals of Chromis hypsilepis were found at all distances. No C. hypsilepis were observed in the southwestern corner of the study area (LB, GI, RO, KA). Labracoglossus nitida, Bathystethus cultratus, and Callanthais allporti were observed only at the Poor Knights.

\section{Species composition and abundance}

The proportional representation of all species of planktivores at 10 locations is presented in Fig. 6. Locations situated to the north and including Hen Island (HE) and the Needles (NE) clustered together. The composition of planktivorous fishes at the Poor Knights Islands, Chickens group, Needles, Hen Island, Mokohinaus and Whangarei Heads was dominated by Chromis dispilus. Goat Island and Kawau were characterised by a high proportional representation of Scorpis aequipinnis and low average abundance of other species. Little Barrier and Rodney showed little similarity with any other location. Trachurus novaezelandiae ranked first in abundance at Rodney by an order of magnitude, while $S$. aequipinnes ranked second. At Little Barrier $C$. dispilus and T. novaezelandiae ranked

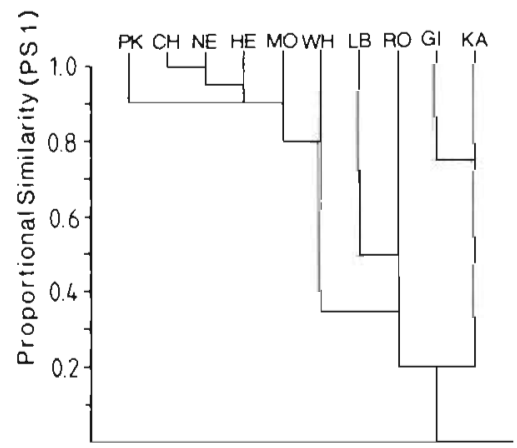

Fig. 6. Dendrogram illustrating the results of cluster analysis (average linkage) using a proportional similarity matrix (value $1.0=100 \%$ similarity). Locations (Fig. 1) are clustered according to proportional representation of species. Abbreviations see Fig. 1

first equal in abundance, while $S$. aequipinnis ranked third.

Total numbers of planktivorous reef fish varied with distance across the continental shelf (Fig. 7). Highest abundances were found at the outer and mid strata shelf (Ryan's test: $d f=36, O=M>I$ ). Highest average abundances were found at the Poor Knights (PK) and

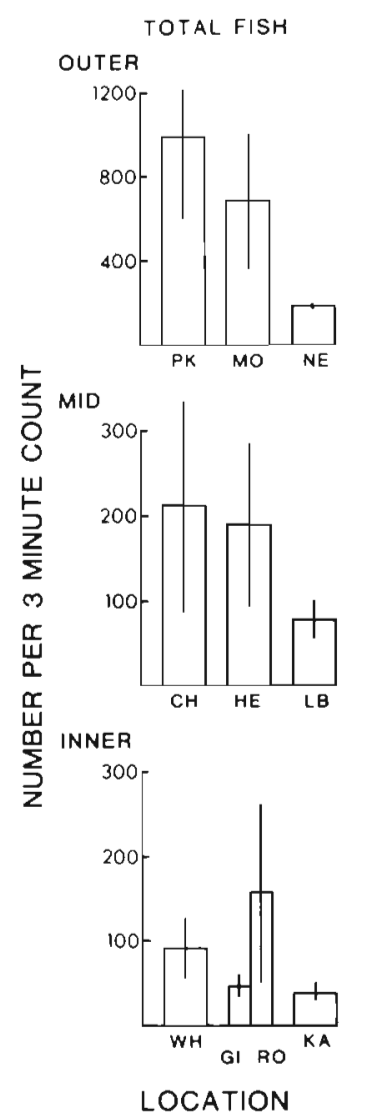

Fig. 7. Total abundance of planktivorous reef fish at inner shelf, mid shelf, and outer shelf locations. Values: as for Figs. 3 to 5 

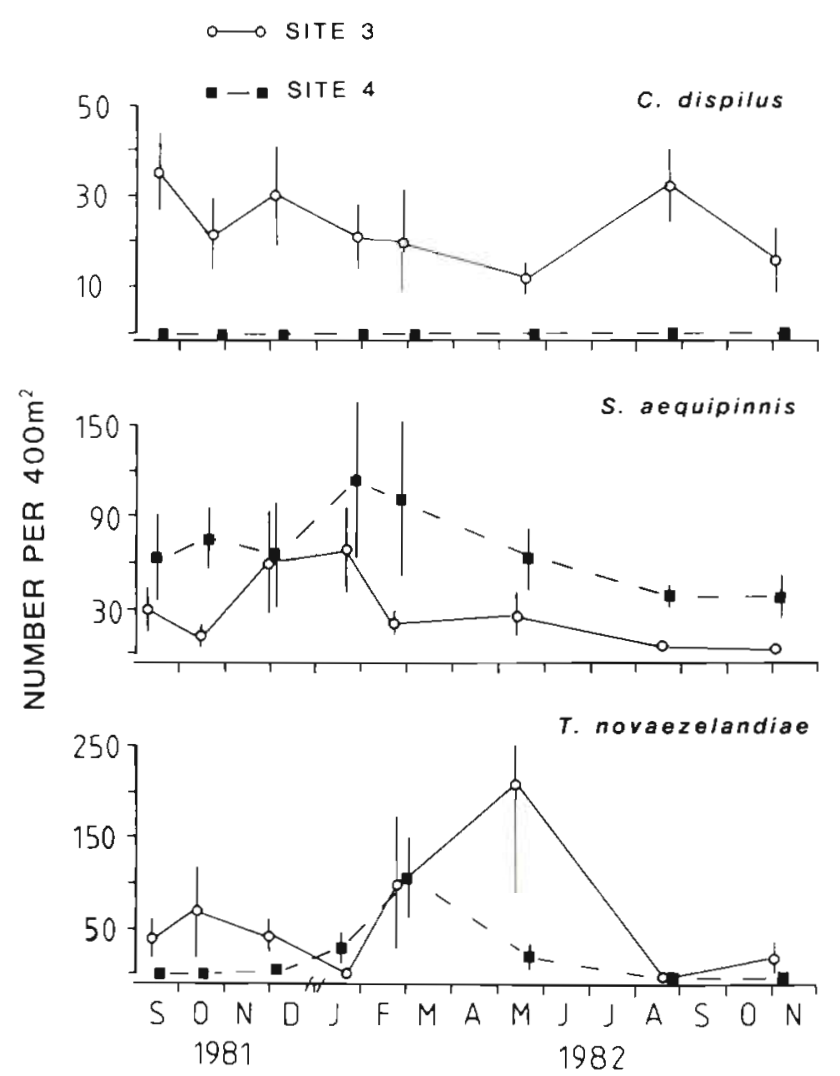

Fig. 9. Chromis dispilus, Scorpis aequipinnis, Trachurus novaezelandiae. Abundance of 3 species of planktivorous reef fish ( $\pm \mathrm{SE}$ ) over 15 mo at 2 sites at Goat Island (see Fig. 1)

in 1982 and 1986 and high abundances of Caprodon longimanus, Scorpis violaceus and Decapterus koheru were observed at both times. S. aequipinnis ranked first in abundance at sites around Goat Island in 1980 and 1986. C. dispilus were not observed at some sites around Goat Island in 1980 reflecting the patterns found in 1986: mean values 1980/1986: 0/0 (Site 1), 0/0 (Site 2), 57/4.2 (Site 3), 0.2/0 (Site 4), 18/1.2 (Site 5). A higher average abundance of $C$. dispilus was recorded at the Poor Knights and Goat Island in 1980/1982 than in 1986

Abundance of planktivorous fish was recorded at
Sites 3 and 4 at Goat Island over a period of $15 \mathrm{mo}$ Chromis dispilus was only found at Site 3 and there was little variation in abundance over the study period (Fig. 9). This pattern was consistent regardless of time of day (Table 5). Casioperca lepidoptera showed the same pattern with average abundance of $8.6 \pm 1.1$ (SE) over $15 \mathrm{mo}$ at Site 3 . No fish were observed at Site 4. Although Scorpis aequipinnis was abundant at both sites for the first 9 mo, low numbers of fish were recorded at Site 3 at the end of the study. Variation in numbers was low between different times of the day (Table 5). The abundance of Trachurus novaezelandiae was characterised by huge changes over 14 mo (Fig. 9). The rankings of sites changed between times. Abundance was sometimes high at both sites (e.g. March) and zero at others (e.g. August). Although variation in abundance was large over 14 mo, regular changes in abundance at different times of the day were not found (Table 5). S. violaceus was found in mean densities of $1.1 \pm 8$ (SE) at Site 3 and $8.3 \pm 4.6$ (SE) at Site 4. Zero values ( 4 at Site 3, 2 at Site 4 ) were found also for this species at times.

\section{DISCUSSION}

Planktivores are the most conspicuous and numerically dominant fish on temperate reefs of northern New Zealand. The abundance of planktivorous fish at many locations, especially at offshore islands, was 1 to 2 orders of magnitude higher than for demersal, benthicfeeding carnivorous and herbivorous fish (Choat \& Ayling 1987, Meekan \& Choat unpubl.). No information is available on broad-scale patterns of abundance for cryptic nocturnal planktivores and piscivores.

Contrasting patterns of abundance were found for 13 species of planktivorous reef fish along $100 \mathrm{~km}$ of the coast of Northland and across the continental shelf. Although no information is available on broad-scale distribution patterns of planktivorous fish in temperate waters, such patterns have been described in tropical waters of the Great Barrier Reef (GBR). Visual counts

Table 5. Densities of 7 species of planktivorous fish at Sites 3 and 4, Goat Island, at 3 times of the day, September 1981. Early 07:30-09:00 h, Mid: 12:30-14:00 h, Late: 16:30-17:30 h. Mean number per $400 \mathrm{~m}^{2}$ (SE)

\begin{tabular}{|lcccccc|}
\hline Species & Early & $\begin{array}{c}\text { Site 3 } \\
\text { Mid }\end{array}$ & Late & Early & $\begin{array}{c}\text { Site } \\
\text { Mid }\end{array}$ \\
\hline C. lepidoptera & $10(6)$ & $7.5(1.5)$ & $12(5)$ & 0 & 0 & 0 \\
D. koheru & $9(6)$ & $0.8(0.8)$ & 0 & 0 & 0 & 0 \\
P. dentex & $0.04(0.04)$ & 0 & 0 & 0 & 0 & 0 \\
T. novaezealandiae & $25(21)$ & $40(2)$ & $20(14)$ & 0 & $0.04(0.04)$ & 0 \\
S. dequipinnis & $25(10)$ & $31(15)$ & $30(12)$ & $45(25)$ & $67(11)$ & $78(56)$ \\
S. violaceus & 0 & 0 & 0 & $16(9)$ & $11(10)$ & $10(10)$ \\
C. dispilus & $38(24)$ & $35(9)$ & $27(10)$ & 0 & 0 & 0 \\
\hline
\end{tabular}


(Williams 1982) and explosives (Williams \& Hatcher 1983) have been used to describe the distribution patterns of planktivorous fish. The GBR is morphologically analogous to my study area in that coral reefs occur across the shelf rather than islands. Surveys on the GBR revealed major differences in species occurrence and abundance at reefs across a shelf measuring $40 \mathrm{~km}$ wide. In contrast to this study, almost no species were found in similar abundances at all distances across the shelf. On the GBR variation in species composition on a north-south axis, along the reef, is small compared to changes across the shelf (Williams et al. 1986). Trends were apparent along a north-south axis in the study. Some species concentrated at the northern end (e.g. Chromis dispilus, Caprodon longimanus) and others at the southern end (e.g. Trachurus novaezelandiae). This probably relates to the geography and hydrology of the area. Contrary to the relatively uniform coastline of eastern Australia, the most southern locations in this study were situated at the outer reaches of a Gulf (Fig. 1). Furthermore, the morphology of the shelf changes; it is broader in the southern part of the study.

Abundance patterns of planktivorous reef fish may be related to the composition and abundance of zooplankton, which in turn may reflect broad-scale differences between water masses. Hydrology may affect both presettlement and postsettlement fish (Cowen 1985, Leis 1986, Kingsford 1988). Planktivorous fish consume plankton on reefs from the time individuals settle until adulthood. The quality and quantity of zooplankton may affect fish growth and abundance (e.g. Williams et al. 1986). Although the reproductive products and early life history forms may spend 3 to $8 \mathrm{wk}$ in the pelagic environment (Kingsford \& Milicich 1987. Kingsford unpubl.), they feed on zooplankton also. Accordingly, their growth and mortality rates may reflect water quality.

Satellite imagery and oceanographic vessels have found that the hydrology of the coast of Northland varies considerably along and across the shelf (Paul 1968, Denham et al. 1984, Harris 1985, J. Zeldis unpubl.). Coolwater upwellings (Zeldis pers. comm.) and warm water intrusions to the northern region of the study area (Denham et al. 1984) generally move south. The entrance to the Hauraki Gulf (area of Rodney and Little Barrier) often marks a hydrological transition between water masses. It is interesting that the locations characterised by a Chromis dispilus dominated fauna correspond to the northern region of the study area. If hydrology is important, presumably the requirements for fish such as Scorpis aequipinnis are quite different. There is considerable potential for investigating cross-shelf distribution patterns of zooplankton and presettlement fish in different watermas- ses as well as the growth of adults and juveniles at reefs across the shelf. Because some fish may remain close to reefs during the presettlement phase (Kingsford \& Choat 1989) it is possible that some species of fish selfseed natal reefs.

Biological oceanography is important on a local scale also. The distribution of planktivorous fish within a reef location has been related to current speed, topographic complexity, density of zooplankton, and quantity of drifting algal fragments (Stevenson 1972, Hobson \& Chess 1976, 1978). Kingsford (1980) and MacDiarmid (1981) found highest abundances of planktivorous fish and number of species in areas around Goat Island that were topographically complex and had high current speeds. Differences in current strength and topographic complexity were not examined in this study. However, differences in these factors probably explain consistent differences between sites for some species. Importantly, differences among sites did not obscure large differences among locations. Information is now required on the settlement patterns of planktivores as well as the subsequent survivorship and movements of recruits to see how they correspond to the distribution patterns of adults among sites.

Distribution patterns were not compared with habitat types within each site. Because the composition of fish varies also between habitats (Ebeling et al. 1980, Choat \& Ayling 1987) counts of planktivorous fish were made across the entire depth range of rocky reef at each site. Accordingly, sampling encompassed a number of habitat types, such as urchin-grazed barrens and kelp forest within each site (see Choat \& Schiel 1982). The contribution of habitat types needs to be investigated on local scale.

Behaviour of the fish is important also. Recognising the degree of association of fish with reefs is important for interpreting interrelationships between fish and the reef community, designing surveys, and the subsequent interpretation of results. Kingsford \& MacDiarmid (1988) recognised that different species of fish associated with rocky reefs to varying degrees. Some species have a very close association with the reef, rarely venturing far from it (e.g. Chromis dispilus, Caesioperca lepidoptera). These fish move in response to changes in current direction and may exhibit migrations at dawn and dusk (Kingsford \& MacDiarmid 1988), but they are always associated with the reef. Other species are considered pelagic planktivores/piscivores (e.g. Trachurus novaezelandiae, Decapterus koheru, Pseudocaranx dentex, Arripis trutta). These species are found in large schools in open water as well as associating with rocky reefs (Clement 1978). Their facultative association with reefs results in large variation in their abundance at a site between times, while densities of $C$. dispilus and other species do not vary in 
this way. Similar patterns were found in this study over a period of $15 \mathrm{mo}$. The peak abundances of $T$. novaezelandiae in autumn corresponded to an input of large numbers of new recruits. Additional information may indicate that juvenile school fish utilise the reef environment more than adults.

Scorpis violaceus showed considerable variation in abundance at a site among times. Casual observations of feeding aggregations from boats and aircraft (pers. obs.) indicated these fish do not move long distances from rocky reefs. They do, however, move far enough to remain undetected in fish counts. Chromis dispilus and Caesioperca lepidoptera were found only at Site 3 and showed little variation in abundance over a period of $15 \mathrm{mo}$. Although there was some variation in abundance of $S$. aequipinnes at Site 4 , this species was always found associated with the reef.

Temporal changes in the composition and abundance of species of reef fish have been described (Ebeling et al. 1980, Choat et al. 1988). Williams (1986) found some variation in species composition with time on the GBR, largely due to changes in habitat type. Broadscale variation across the shelf, however, was not obscured by these changes. Data collected by Kingsford \& MacDiarmid (unpubl.) allowed a preliminary assessment of temporal changes over $5 \mathrm{yr}$. Rank abundance of species at Goat Island and the Poor Knights remained similar in 1980-82 and 1986 (Table 4). It seems unlikely, therefore, that major differences in species composition and abundance between inner, mid, and outer shelf strata disappear between years. Chromis dispilus showed a reduction in average abundance at the Poor Knights and Goat Island in 1986 (cf. 1980-82). This may represent only a temporary change in the abundance of this species, similar to those recorded for labrid fish at the Poor Knights over a period of 13 yr (Choat et al. 1988). More information is needed on the abundance of carangids on the scale of a location. Until then large differences in composition that are due to the presence of groups such as carangids should be treated with caution as they may change with time. For example, with the exception of Trachurus novaezelandiae, Rodney was typical of other 'inner' locations (Goat Island and Kawau), having low densities of $C$. dispilus and moderate densities of Scorpis aequipinnis. Although low densities of $T$. novaezelandiae were recorded at Goat Island during the broad-scale survey, high densities have been found there in the past (Fig. 9).

In conclusion, the species composition and abundance of planktivorous reef fish varied within the study area. This would suggest that any effect fish have on zooplankton and their contribution to reef environments through the input of nutrients would also vary with area. Planktivorous species that are closely associ- ated with reefs have been identified. The investigation of proximate factors which determine patterns of distribution is an important avenue for future research. It should focus on differences across the shelf that relate to water quality, distribution of presettlement fish, settlement patterns of planktivores and subsequent survivorship.

Acknowledgements. I thank the skippers of RV 'Proteus', M. Kampman, and especially B. Doak, for their assistance during the survey. Thanks to $M$. Sewell who assisted in the field and $J$. Jeffrey and $M$. Ricketts for help with the figures. I acknowledge funding from the New Zealand Ministry of Agriculture and Fisheries and R. G. Creese who obtained support through the Leigh Marine Reserve Committee. I was supported by an Australian Marine Sciences and Technologies Grant while the paper was written. W. Steel and K. McGuiness gave useful advice on analyses of the data. For their critical appraisal of the original manuscript I thank J. H. Choat, A. B. MacDiarmid, $\mathrm{J}$. Zeldis and the anonymous referees.

\section{LITERATURE CITED}

Ayling, T., Cox. G. T (1982). Collins guide to the sea fishes of New Zealand. Collins, Auckland

Begun, J. M., Gabriel, K. R. (1981). Closure of the NewmanKeuls multiple comparison procedure. J. Am. statist. Ass. 76: 241-245

Bortone, S. A., Hastings, R. W., Oglesby, J. L. (1986). Quantification of reef fish assemblages: a comparison of several in situ methods. Northeast Gulf Sci. 8: 1-22

Bray, R. N. (1981). Influence of water currents and zooplankton densities on daily foraging movements of blacksmith Chromis punctipinnis, a planktivorous reef fish. Fish. Bull U. S. 78: 829-841

Bray, R. N., Miller, A. C., Geesey, G. G. (1981). The fish connection: a trophic link between planktonic and rocky reef communities. Science 214: 204-205

Bray, R. N., Purcell, L. J., Miller, A. C. (1986). Ammonium excretion in a temperate-reef community by a planktivorous fish, Chromis punctipinnis (Pomacentridae), and potential uptake by young giant kelp, Macrocystis pyrifera (Laminariales). Mar Biol. 90: 327-334

Choat, J. H., Ayling, A. M. (1987). The relationship between habitat structure and fish faunas. J. exp. mar. Biol. Ecol. 110: $257-284$

Choat, J. H., Ayling, A. M., Schiel, D. R. (1988). Temporal variation in an island fauna. J. exp. mar Biol. Ecol. 121: 91-112

Choat, J. H., Schiel, D. R. (1982). Patterns of distribution and abundance of large brown algae and invertebrate herbivores in subtidal regions of northern New Zealand. J. exp. mar. Biol. Ecol. 60: 129-162

Clement, I. T. (1978). School fish sightings around New Zealand, 1976-1977. N. Z. Fish. Res. Div. Occas. Publ. No. 15

Cowen, R. K. (1985). Large scale patterns of recruitment by the labrid Semicossyphus pulcher: causes and implications. J. mar. Res. 43: 719-742

Denham, R. N., Bannister, R. W., Guthrie, K. M., Crook, F. G. (1984). Surveys of the East Auckland and East Cape Currents, New Zealand. Aust. J. mar. Freshwat. Res. 35 491-504

Doak, W. (1972). Fishes of the New Zealand region. Hodder and Stoughton, Auckland 
Ebeling, A. W., Bray. R. N. (1976). Day versus night activity of reef fishes in a kelp forest off Santa Barbara, California. Fish. Bull. U. S. 74: 703-717

Ebeling, A. W., Larson, R. J., Alevizon, W. S., Bray, R. N. (1980). Annual variability of reef-fish assemblages in kelp forests off Santa Barbara, California. Fish. Bull. U.S. 78 : 361-377

Gaines, S. D., Roughgarden, J. (1987). Fish in offshore kelp forests affect recruitment to intertidal barnacle populations. Science 235: 479-481

Harris, T. F. W. (1985). North Cape to East Cape: aspects of physical oceanography. University of Auckland Marine Laboratory report, Leigh

Hobson, E. S., Chess, J. R. (1976). Trophic interactions among fishes and zooplankters near shore at Santa Catalina Island, California. Fish. Bull. U. S. 74: 567-598

Hobson, E. S., Chess, J. R. (1978). Trophic interactions among fishes and plankton in Enewetak Atoll, Marshall Islands. Fish. Bull. U. S. 76: 133-153

Jones, G. P. (1984). Population ecology of the temperate reef fish Pseudolabrus celidotous (Pisces: Labridae). II. Factors influencing adult density. J. exp. mar. Biol. Ecol. 75: 277-303

Kingsford, M. J. (1980). Interrelationships between spawning and recruitment of Chromis dispilus (Pisces Pomacentridae) M. Sc. thesis, Univ of Auckland

Kingsford, M. J., Choat, J. H. (1989). Horizontal distribution patterns of presettlement reef fish: are they influenced by the proximity of reefs? Mar. Biol. in press

Kingsford, M. J., Milicich, M. J. (1987). Presettlement phase of Parika scaber (Pisces: Monacanthidae): a temperate reef fish. Mar. Ecol. Prog. Ser. 36: 65-79

Kingsford, M. J., MacDiarmid, A. B. (1988). Interrelationships between planktivorous reef fish and zooplankton in temperate waters. Mar. Ecol. Prog. Ser. 48: 103-117

Kohn, A. J., Riggs, A. C. (1982). Sample size dependence in measures of proportional similarity. Mar. Ecol. Prog. Ser. 9: $147-151$

Larson, R. J., DeMartini, E. E. (1984). Abundance and vertical distribution of fishes in a cobble-bottom kelp forest off San Onofre, California Fish. Bull. U. S. 82: 37-53

Leis, J. M. (1986). Ecological requirements of Indo-Pacific larval fishes: a neglected zoogeographic factor. In: Uyeno, T., Arai, R., Taniuchi, K., Matsuura, K. (eds.) Indo-Pacific fish biology. Proc. 2nd Int. Conf. on Indo-Pacific Fishes Ichthyological Society of Japan, Tokyo, p. 759-766

MacDiarmid, A. B. (1981). Factors influencing the distribution

This article was submitted to the ditor and abundance of two temperate planktivorous reef fish. M. Sc. thesis, Univ. of Auckland

Paul, L. (1968). Some seasonal water temperature patterns in the Hauraki Gulf, New Zealand, N.Z. Jl Mar. Freshwat. Res. 2: 535-558

Paulin, C. D., Stewart, A. L. (1985). A list of New Zealand teleost fishes held in the National Museum of New Zealand. Brownsey, P. J. (ed.) National Museum of New Zealand Miscellanous series No. 12

Robertson, D. R. (1982). Fish feces as food on a Pacific coral reef. Mar. Ecol. Prog. Ser 7: 253-265

Russ, G. (1984). Distribution and abundance of herbivorous grazing fishes in the central Great Barrier Reef. I. Levels of variability across the entire continental shelf. Mar. Ecol. Prog. Ser. 20: 23-34

Russell, B. C. (1977). Population and standing crop estimates for rocky reef fishes of north eastern New Zealand. N. Z. Jl mar. Freshwat. Res. 11: 23-36

Russell, B. C. (1983). The food and feeding habits of rocky reef fish of north-eastern New Zealand. N. Z. Jl mar. Freshwat. Res. 17: 121-145

Siegel, S. (1956). Non-parametric statistics for the behavioral sciences. McGraw-Hill Kogakusha Ltd Tokyo

Stevenson, Jr., R. A. (1972). Regulation of feeding behavior of the bicolor damselfish (Eupomacentrus particus Poey) by environmental factors. In: Winn, H G. (ed.) Behavior of marine animals. 2: Vertebrates. Plenurn, New York, p. 278-302

Thresher, R. E., Gunn, J. S. (1986). Comparative analysis of visual census techniques for highly mobile, reef associated piscivores (Carangidae) Environ. Biol. Fish. 17. 93-116

Underwood, A. J. (1981). Techniques of analysis of variance in experimental marine biology and ecology. Oceanogr. mar. Biol. A. Rev. 19: 513-605

Williams, D. McB. (1982). Patterns in the distribution of fish communities across the central Great Barrier Reef. Coral Reefs 1. 35-43

Williams, D. McB. (1986). Temporal variation in the structure of reef slope fish communities (central Great Barrier Reef): short term effects of Acanthaster planci infestation. Mar. Ecol. Prog. Ser. 28: 157-164

Williams, D. McB., Hatcher, A. I. (1983). Structure of fish communities on outer slopes of inshore, mid-shelf and outer shelf reefs of the Great Barrier Reef. Mar. Ecol. Prog Ser. 10: $239-250$

Williams, D. McB., Russ, G. R., Doherty, P. J. (1986). Reef fish: large-scale distribution and recruitment. Oceanus 29: 76-82

Manuscript first received: February 24, 1988

Revised version accepted: March 1, 1989 